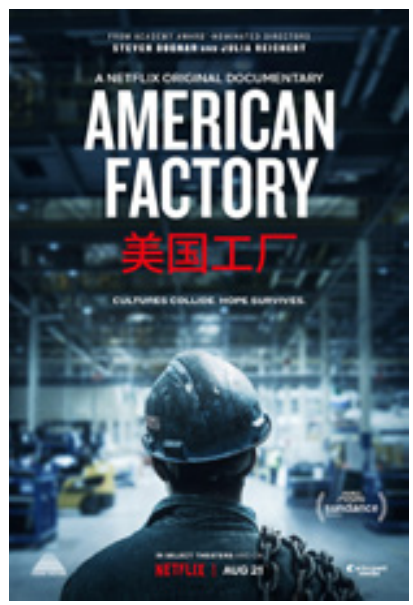

American Factory by Steven Bognar and Julia Reichert (2019).

\section{Service for Influence? \\ The Chinese Communist Party's \\ Negotiated Access to Private \\ Enterprises}

\section{Hong ZHANG}

mong the many praises for the documentary American Factory, the filmmakers' non-judgmental way of storytelling is a major point. Their determination not to villainise any individual indeed conveys a commendable commitment to humanity-in an age of polarisation when people are used to pointing fingers at others, this film is refreshing. This was supposedly also why the Obamas' Higher Ground Productions got behind it-it represented the kind of message they wanted to channel into American public discourse.

While the documentary is an artistic victory, it is less satisfying intellectually. The film takes the American audience on a rare tour observing the life of the Chinese workers in Fuyao's headquarters in Fuqing city, Fujian province. There, it highlights the military training-style team meetings, the extravagant New Year party, the collective wedding, and the willingness to endure hardship. But it does not provide a good explanation of why these things are happening. 'This is just the Chinese culture' seems to be the answer the filmmakers leave the audience with, and in fact this is the conclusion many American reviewers have drawn from the film. But what exactly is this 'culture'? Unfortunately, rather than illuminating the specific forces that contributed to shaping the outlook of the Chinese workers, American Factory follows the familiar practice of depicting their behaviour as something uniquely Chinese and foreign. This presents the viewer with an essentialist understanding of cultural differences.

To me, a student of China's political economy, the most interesting revelation in the film comes when the crew interview the chairman of Fuyao Group's trade union, $\mathrm{Mr} \mathrm{He}$ Shimeng. Mr He wears many hats. He is not only the union's leader, but also a Vice-president of Fuyao Group, as well as the Secretary of the Chinese Communist Party (CCP) Committee at the company, and a brother-in-law of Mr Cao Dewang, Fuyao's founder and Chairman of the Board. It immediately begs a number of questions: what role does the Party play in a private 
enterprise such as Fuyao? What is the relationship between the Party organisation, the company's management, and the workers? How does this relationship shape the workers' experience in the workplace?

It turns out that the CCP has a long presence in Fuyao. Established in 1987 in a de facto privatisation of a townshipand-village enterprise, the firm set up its first Party Branch (党支部) in 1997, which was upgraded to a Party Committee (党委) in 2007 overseeing five branches in the company. As of 2019, Fuyao Group has 623 CCP members (Fuzhou News 2019). It may seem a small proportion of the company's 22,000-strong Chinese staff, but over 70 percent of Party members occupy key positions in the management or technical leadership, including 22 senior executives (People.com.cn 2016). Fuyao's Party organisation has also won multiple awards from the provincial Party authorities for its stellar performance in Party work in a private enterprise (Duan 2016).

Interestingly, as Mr Cao retells in his memoir, back in 1989 he used to resist setting up a CCP committee in his company, as he was concerned about possible confusion over the decisionmaking power (Fuyao Group 2018). What, then, explains Fuyao's later embrace of the Party organisation? It may have been political pressure, but for now $\mathrm{Mr}$ Cao and Fuyao appear to have found a comfortable way of coexisting with the Party. Not least because by utilising the CCP's time-honoured repertoire for mobilisation and indoctrination, the Party organisation has presented itself as a tool for corporate management, which has convinced private entrepreneurs such as $\mathrm{Mr}$ Cao of its usefulness.

As $\mathrm{Mr}$ He's various titles suggest, the relationship between the Party organisation, the management, and the trade union is characterised by integration rather than separation. Similar to the situation in state-owned enterprises (SOEs), Fuyao institutionalises a cross-posting system where the leadership positions in the CCP committee are taken up by senior executives who are Party members. However, unlike in SOEs where the chairperson of the board and the Party chief are required to be the same person to ensure that the CCP has a final say in corporate decision-making (SASAC 2018), Fuyao's chairman does not hold a Party position, and the Party organisation has no control over the board.

As such, the CCP organisation plays a supporting role in Fuyao by engaging in employee management. This is done not only through the Party branches and cells, but also through the Party's oversight over the union and the Communist Youth League. Besides Mr He's multi-posting, a deputy Party secretary serves as the deputy union chairman, and a member of the 
Party Committee serves as the secretary of the Youth League. Through the latter two, the Party organisation has access to the majority of the employees.

Reflecting the CCP's mass work tradition, Fuyao's Party organisation develops extensive ties with employees. To start with, the Party organisation takes charge of employee welfare. It not only supervises the mandatory social insurance and pension schemes, but also provides 'extra' welfare programmes, such as building libraries and sports facilities for the employees. The New Year party featured in the documentary would most likely have involved the Party organisation. In addition, it rolls out various mechanisms to facilitate its communications with the employees and keep it informed of the dynamics within the workforce: a hotline is available for employees to appeal to Party cadres for help with their personal difficulties or complaints; each Party member is mandated to liaise with one key technician, one candidate for Party membership, and one employee in distress.

Such access to the workforce allows the Party organisation to develop an incentive scheme: employees considered crucial for the company's development are recruited into the Party, and Party membership in turn grants them greater influence in the workplace. Loyalty and technical or management capabilities are the most sought-after qualities for Party member candidates. The Party organisation slates employees who have worked in Fuyao for over three years to make up the priority pool for prospective Party member candidates (People.com. cn 2016). Employees showing greater potential for technical or management leadership are selected and groomed through the Party's training programmes, and their final attainment of Party membership marks them out for career promotion within the company. Party members also have privileged access to the company's strategic decisions; in some cases they are allowed to participate in their deliberation.

Party organisations in the workplace seek to incorporate the Communist Party's vanguardism. In the case of Fuyao, it is embodied by the Party members' role in spearheading technological innovation. Through sponsoring 'CCP member innovation groups' and organising 'innovation contests' among them, the Party organisation in Fuyao positions itself to lead the company's innovation efforts, which is crucial for the company's survival in the global auto industry's cut-throat competition. Party members are also entrusted to critical missions of the 
company, of which the Dayton factory is a prime example. Ten Party members were among those dispatched to Dayton, including three in leadership positions (Minzuxuan 2016).

To sum up, Fuyao's Party organisation effectively serves as something analogous to a Western corporation's human resources (HR) department. It may be argued that the CCP organisations provide HR services to private enterprises, which are often not very strong in corporate governance, in exchange for access to these companies. The CCP's principle of engaging private enterprises is summarised by the mantra of "presence without intrusion, action without disruption, induction without interference' (到位不越位、有为不乱为、引导不干预) (People.com.cn 2016). This suggests that while the CCP is firm in demanding its place in private companies, it is careful when pushing boundaries.

But whatever practical roles the Party organisations take on in private enterprises, they remain political organisations embedded in the CCP's network globally, through which the Party's central leadership disseminates policies. According to the CCP's organisational rules, Fuyao's Party branches in its headquarters and subsidiaries across China must report to their local Party-state authorities. In its headquarters in Fuqing, the company's Party Committee works closely with the city's Party Committee, including frequently hosting political/ cultural events organised by the latter (Fuqing City 2019a). Recent examples include a patriotic song concert that saw the participation of 12 local companies (Fuqing City 2019b). Fuyao also has an in-house Party School, where Party members routinely attend study sessions on the Party's doctrines and policies. Joining in the national propaganda campaign based on the Xuexi Qiangguo (学习强国) app, Fuyao recently organised a contest for its Party-member employees, who were quizzed about everything from natural science, to art, Marxism, CCP history, and military affairs (Fuqing City 2019c).

As the directors of the documentary recalled in an interview: 'The Chinese folks are really on a mission for the company to succeed, but also for their country to succeed. The Americans felt no such sense of mission, except at the beginning when they were grateful for those jobs.' 'Our Chinese producers explained to us that appeals to patriotism or nationalism within a Chinese context are pretty common, in a lot of companies' (Wilkinson 2019). The directors provided this as an example of a perceived Chinese cultural uniqueness. But can these behaviours be entirely attributed to 'Chinese culture'? I doubt that such 
manifestation of patriotism and loyalty to the company would have been possible without the Party organisation's active mobilisation and indoctrination.

The case of Fuyao may not be generalisable to all private enterprises in China, but it certainly is a window for us to peer into the relationship between the CCP and heavyweight private enterprises. The CCP needs to negotiate its access into private enterprises; private entrepreneurs need to balance the political reward that may come with allowing the Party organisation into their companies against their loss of control over certain aspects of corporate management. But as the CCP steps up its push for Party-building in private enterprises, entrepreneurs may increasingly find themselves squeezed at the negotiation table. 